\title{
Kaidah Fiqh dan Ushul Fiqh Tentang Produk Halal, Metode Istinbath dan Ijtihad dalam menetapkan Hukum Produk Halal
}

\author{
Ratna Wijayanti \\ Fakultas Ekonomi Universitas Sains Al-Qur'an Jawa Tengah di Wonosobo \\ E-mail:wijayantiratna34@yahoo.co.id \\ Meftahudin \\ Fakultas Ekonomi Universitas Sains Al-Qur'an Jawa Tengah di Wonosobo \\ E-mail:meftahudin72@gmail.com
}

\begin{abstract}
The purpose of the discovery of Islamic law must be understood by the mujtahid in order to develop legal thinking in Islam in general and answer contemporary legal issues whose cases are not explicitly regulated by the Koran and Hadith, especially those related to the field of muamalah. In reviewing the matter to be determined by law, the Indonesian Ulema Council Fatwa Commission is based on the Qur'an and Sunnah as its main source. In this context, there are several methods used by the Indonesian Ulema Council Fatwa Commission. First, every Fatwa Decree must have a basis on the Book of Allah and the Sunnah of the Apostle that is not bad, and not contrary to the benefit of the people. Second, if it is not found in the Book of Allah and the Sunnah of the Apostles, the Fatwa Decree should not contradict ijma ; qiyas that mu'tabar, and other legal arguments, such as ihtisan, maslahah mursalah, and saddu al-dzari'ah. Third, before making a decision before deciding on a fatwa, it must first be carefully studied for each problem presented to the MUI at least a week before the trial. If the problem is clear the law (qath'iy) let the commission convey it as it is, and the fatwa will fall after the text is known from the Koran and the Sunnah. Whereas in the case of khilafiyah occurring among the schools of thought, what is stated is the result of tarjih after observing the jurisprudence of muqaran (comparison) using the rules of ushul fiqh muqaran related to scholarship.
\end{abstract}

Keywords: Al-Qur'an; Fatwa; Hadist; Istinbath; Ijtihad 


\begin{abstract}
ABSTRAK
Tujuan penemuan hukum Islam haruslah dipahami oleh mujtahid dalam rangka mengembangkan pemikiran hukum dalam Islam secara umum dan menjawab persoalan-persoalan hukum kontemporer yang kasusnya tidak diatur secara eksplisit oleh Al- Qur'an dan Hadits, terutama yang terkait dengan bidang muamalah. Dalam melakukan pengkajian masalah yang akan ditentukan hukumnya, Komisi Fatwa Majelis Ulama' Indonesia mendasarkan pada al-Qur'an dan Sunnah sebagai sumber pokok. Dalam kontek ini, ada beberapa metode yang digunakan oleh Komisi Fatwa Majelis Ulama' Indonesia. Pertama, Setiap Keputusan Fatwa harus mempunyai dasar atas Kitabullah dan Sunnah Rasul yang mu'tabarah, serta tidak bertentangan dengan kemaslahatan umat. Kedua, Jika tidak terdapat dalam Kitabullah dan Sunnah Rasul, Keputusan Fatwa hendaklah tidak bertentangan dengan ijma', qiyas yang mu'tabar, dan dalil-dalil hukum yang lain, seperti ihtisan, maslahah mursalah, dan saddu al-dzariah. Ketiga, Sebelum pengambilan Keputusan sebelum menetapkan suatu fatwa, harus terlebih dahulu dipelajari setiap masalah yang disampaikan kepada MUI dengan seksama sekurang-kurangnya seminggu sebelum disidangkan. Jika persoalannya telah jelas hukumnya (qath'iy) hendaklah komisi menyampaikan sebagaimana adanya, dan fatwa menjadi gugur setelah diketahui nash-nya dari Al-Quran dan Sunnah. Sedangkan dalam masalah yang terjadi khilafiyah di kalangan madzhab, maka yang difatwakan adalah hasil tarjih setelah memperhatikan fikih muqaran (perbandingan) dengan menggunakan kaidah-kaidah ushul fiqih muqaran yang berhubungan dengan pentarjihan.
\end{abstract}

Kata Kunci: Al Qur’an, Hadist, Istinbath, Ijtihad, Fatwa.

\title{
Pendahuluan
}

Sumber pokok hukum Islam adalah Al-Quran dan As-Sunnah. Ulama berpendapat bahwa di dalam syariat Islam telah terdapat segala hukum yang mengatur semua tindak tanduk manusia, baik perkataan maupun perbuatan. Hukum-hukum itu ada kalanya disebutkan secara jelas serta tegas dan ada kalanya dikemukakan dalam bentuk dalil-dalil dan kaidah kaidah secara umum. Untuk memahami hukum Islam dalam bentuk yang pertama tidak diperlukan Ijtihad, tetapi cukup diambil begitu saja dan diamalkan apa adanya, karena memang sudah jelas dan tegas disebut oleh Allah. Hukum Islam dalam bentuk ini disebut Wahyu murni. Adapun untuk mengetahui hukum Islam dalam bentuk yang 
kedua diperlukan upaya yang sungguh-sungguh oleh para mujtahid untuk menggali hukum yang terdapat di dalam nash melalui pengkajian dan pemahaman yang mendalam yang disebut juga dengan fikih (Abd. Al-Wahhab Khallaf 1972, 11).

Dalam versi lain, fiqih juga disebut sebagai koleksi (majmu') hukum- hukum syariat yang berkaitan dengan perbuatan mukallaf dan diambil dari dalil-dalillnya yang tafshili (Abd. Al-Wahhab Khallaf 1972, 12). Dalil- dalil yang tafshili maksudnya adalah dalil-dalil yang terdapat dan terpapar dalam nash dimana satu persatunya menunjuk pada satu hukum tertentu (Satria Effendi M Zein 2009).

Sebelum Islam, seluruh agama peranannya hanya terbatas pada mensucikan jiwa dan meningkatkan kedudukan manusia. Dalam syariat Islam terdapat dua bidang yaitu bidang ibadah dan bidang muamalah (Alkaf Idrus 1998). Syariat Islam adalah Universal, dengan sifat Universal ini berarti cocok (sesuai dan selaras) buat manusia dimanapun mereka berada. Untuk membuktikan keuniversalannya itu kita harus menggunakan Ijtihad, dengan berijtihad kita dapat menyesuaikan dan menyelaraskan keadaan dan tempat dengan patokan-patokan umum yang dikandung syariat Islam.

Pada masa Rasul, manakala muncul suatu persoalan hukum, baik yang berhubungan dengan Allah maupun kemasyarakatan, Allah menurunkan ayat-ayat Al-Quran untuk menjelaskannya. Rasul sebagai muballig, menyampaikan penyampaian penjelasan ini kepada umatnya untuk di ikuti. Kendati demikian, penjelasan Al-Quran tersebut tidak selamanya tegas dan terperinci (tafsili), melainkan kebanyakan bersifat garis besar (ijmali), sehingga di butuhkan lebih lanjut dari Rasul. Sebagai orang yang diberi wewenang menjelaskan di satu sisi dan menghadapi realitas sosial yang berkembang di sisi lain, Rasul terkadang harus menggunakan akal yang di sebut dengan ijtihad dalam penerapan hukum Islam.

Seiring dinamika zaman yang berubah maka sumber diatas membutuhkan Istinbath dengan cara analis (ijtihad) meskipun secara historis sudah ditutup yang kemudian ulama modernis untuk 
membukanya kembali dan dilakukan oleh ulama dunia (termasuk Indonesia) dengan berbagai pendekatan dan metode (Jaih Mubarok 2002, 169). Proses ijtihad tidak terbatas pada persoalan yang baru muncul, tetapi ijtihad mempunyai kepentingan lain yang berkaitan dengan khazanah hukum islam yaitu dengan melakukan peninjauan kembali terhadap masalah-masalah yang ada berdasarkan kondisi yang ada pada zaman sekarang dan kebutuhan-kebutuhan manusia untuk memilih mana pendapat yang terkuat dan relevan, dengan merealisasikan tujuan-tujuan syariat dan kemaslahatan manusia.

Tujuan penemuan hukum haruslah dipahami oleh mujtahid dalam rangka mengembangkan pemikiran hukum dalam Islam secara umum dan menjawab persoalan-persoalan hukum kontemporer yang kasusnya tidak diatur secara eksplisit oleh Al-Quran dan Hadits khususnya dalam segala cabang dari bidang muamalah, yang belum ada ketetapan hukumnya. Salah satunya adalah bagaimana penetapan produk halal. Semua makanan yang ada di dunia ini pada dasarnya halal. Boleh dimakan. Tidak ada satupun makanan yang haram, kecuali jika Allah telah menetapkannya (Sarwat Ahmad 2003, 2). Oleh karenanya dengan berbagai macam metode yang diterapkan diharapkan akan dapat menemukan hukum-hukum dalam memecahkan berbagai persoalan yang muncul dalam keadaan sosial dan teretorial yang berbeda, Kenyataan yang demikian, maka Indonesia sebagai negara yang penduduknya terdiri dari beberapa suku dan mayoritas Islam tergugah untuk menjawab tantangan yang ada demi tercapainya perpaduan budaya, agama, dan tradisi yang majemuk, sembari memasuki era perkembangan modern, tanpa menyia-nyiakan nilai-nilai keIslamannya. Makalah ini ditulis dengan tujuan untuk menguraikan bagaimana kaidah Fiqh dan ushul fiqh produk Halal, bagaimana metode Istinbath dan Ijtihad dalam menetapkan Hukum Produk Halal.

\section{Kaidah Fiqh dan Ushul Fiqh Produk Halal}

Dari uraian diatas terlihat perbedaan yang nyata antara ilmu fiqih dan ilmu ushul fiqh. kalau Ilmu fiqih berbicara tentang hukum dari sesuatu perbuatan, maka ilmu ushul fiqh bicara tentang metode dan proses bagaimana menemukan hukum itu sendiri. Ilmu fiqih berbicara tentang hukum dari sesuatu perbuatan, maka ilmu ushul fiqh bicara 
tentang metode dan proses bagaimana menemukan hukum itu sendiri atau kumpulan kaidah atau metode yang menjelaskan kepada ahli hukum Islam tentang cara mengeluarkan hukum dari dalil-dalil syara' (Koto Alaiddin 2004, 4).

Pada pokoknya yang menjadi obyek dalam ilmu fiqih adalah perbuatan mukallaf dilihat dari sudut hukum syara' yaitu ibadah, mu'amalah dan 'uqubah (Koto Alaiddin 2004, 5). Pada bagian ibadah tercakup segala persoalan yang pada pokoknya berkaitan dengan urusan akhirat, bagian mu'amalah mencakup hal-hal yang berhubungan dengan harta, dan bagian 'uqubah mencakup segala persoalan yang menyangkut tindak pidana, bagian ini juga membicarakan hukuman-hukuman seperti qiyas, had, diyat dan ta'zir (Syarifuddin Halim 2005, 93).

Abdul wahab Khallaf mengatakan bahwa maksud akhir yang hendak dicapai dari ilmu fikih adalah penerapan hukum syariat kepada amal perbuatan manusia, baik tindakan maupun perkataannya (Abd. Al-Wahhab Khallaf 1972, 14). di dalamnya akan dipelajari mana yang diperintah dan mana yang dilarang, mana yang sah dan mana yang batal, mana yang halal dan mana yang haram, dan lain sebagainya. Ilmu ini diharapkan muncul sebagai rujukan bagi para hakim pada setiap keputusannya, bagi para ahli hukum di setiap pendapat dan gagasannya, dan juga bagi setiap mukallaf pada umumnya dalam upaya mereka mengetahui hukum syariat dari berbagai masalah yang terjadi akibat tindak tanduk mereka sendiri.

Begitu juga dengan ilmu ushul fiqih, khallaf berpendapat tujuan akhir yang hendak dicapai dengan ilmu ini adalah penerapan kaidahkaidah dan pembahasan-pembahasannya kepada dalil-dalil tafshili untuk sampai kepada hukum syariat yang ditunjuk oleh dalil-dalil tersebut. Ilmu ini membicarakan metode penerapan hukum bagi peristiwaperistiwa atau tindakan yang secara pasti tidak ditemui nashnya, yaitu dengan jalan qiyas, istishab, ijtihad dan sebagainya (Koto Alaiddin 2004, 14-15). Dengan ilmu ini diharap umat Islam terhindar dari taqlid, ikut pendapat orang lain tanpa mengetahui alasan-alasannya. 


\section{Halal dalam Kaidah Fiqh}

Halal (حلال, halāl, halaal) adalah istilah bahasa Arab dalam agama Islam yang berarti "diizinkan" atau "boleh". Istilah ini dalam kosakata sehari-hari lebih sering digunakan untuk merujuk kepada makanan dan minuman yang diizinkan untuk dikonsumsi menurut Islam. Halal ialah sesuatu yang mubah (diperkenankan), yang terlepas dari ikatan larangan, dan diizinkan oleh Pembuat Syari’at untuk dilakukan.

Imam Al - Ghazali di dalam memberikan makna halalan thayyiban tampaknyaberbeda dengan pendapat diatas. Menurutnya sesuatu dikatakan halalan thayyiban dari segi zat bendanya sendiri itu diperoleh dengan cara yang baik, tidak berbahaya, tidak memabukkan dan dikerjakan menurut syariat agama. Jadi halal adalah segala sesuatu yang dihalalkan Allah. Sedangkan dalam konteks yang lebih luas istilah halal merujuk kepada segala sesuatu yang diizinkan menurut hukum Islam (aktivitas, tingkah laku, cara berpakaian dan lain sebagainya). Menurut Abdul Aziz Dahlan dalam Ensiklopedi Hukum Islam, disebutkan bahwa halalan thayyiban mengandung beberapa makna yaitu membebaskan, melepaskan, memecahkan, membubarkan, dan membolehkan. Artinya segala sesuatu yang menyebabkan seseorang tidak dihukum jika menggunakannya dan sesuatu yang boleh dikerjakan menurut syara. Sedangkan pengertian sesuatu yang boleh dikerjakan menurut syara' ini berkaitan dengan kebolehan memanfaatkan, memakan, meminum, dan mengerjakan sesuatu yang telah ditentukan berdasarkan nash atau mengandung arti sebagai anjuran untuk mengerjakan sesuatu yang berdasarkan nash.

Pengertian lain halal dalam bahasa Arab berasal dari kata halla, yahillu, hillan, yang berarti membebaskan, melepaskan, memecahkan, membubarkan dan membolehkan (Abdul Aziz Dahlan 1997, 505). Sedangkan secara etimologi halal berarti hal-hal yang boleh dan dapat dilakukan karena bebas atau tidak terikat dengan ketentuanketentuan yang melarangnya (Aisjah Girindra 1998, 20). Dalam al-Qur'an istilah halal juga diungkapkan dengan istilah atthayyib, sebagaimana yang disebutkan dalam surat (Abdul Aziz Dahlan 1997):

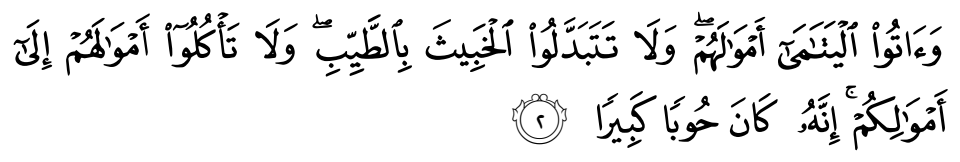


Artinya : "Jangan kamu menukar yang baik dengan yang buruk" (Qs. An-Nisa' : 2)

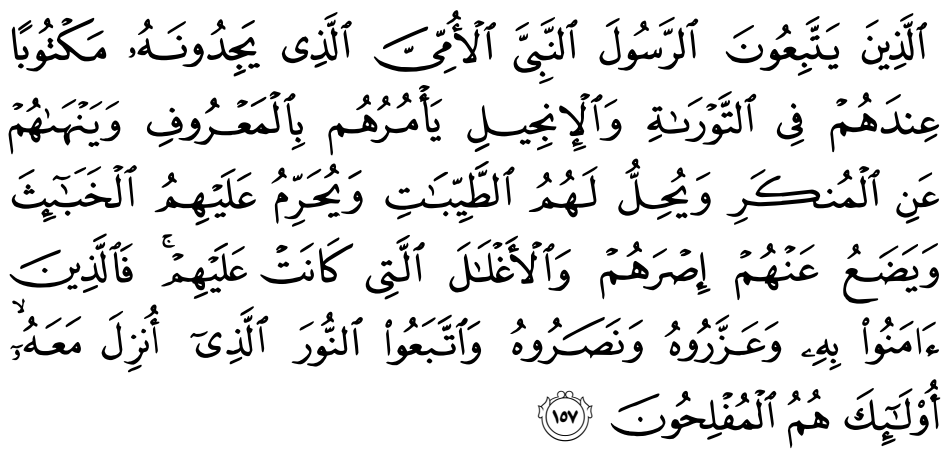

Artinya : "Dan menghalalkan kepada mereka segala yang baik dan mengharamkan kepada mereka segala yang buruk...". (Qs. Al-A'raf : 157)

Sedangkan kata thayyib berarti lezat, baik, sehat, mententramkan dan paling utama. Dalam konteks makanan kata thayyib berarti makanan yang tidak kotor dan segi zatnya atau rusak (kadaluwarsa) atau tercampur dengan benda najis (Aisjah Girindra 1998, 20) .

Kriteria halal menurut ulama Fiqih Menentukan halal atau tidaknya suatu urusan adalah sesuatu yang paling asasi dalam hukum Islam (Thabieb al-Asyhar 2003, 87). Menurut pandangan ulama fiqih, dalil-dalil di atas (ayat tersebut) merupakan pengetahuan yang bersifat keyakinan bahwa Allah-lah satu satu-Nya Dzat yang paling berhak menentukan halal-haramnya sesuatu. Secara teologis, pengharaman dan penghalalan suatu di luar otoritas yang dipunyai Allah adalah perbauran yang bisa dilkategorikan syirik (Thabieb alAsyhar 2003, 88). Segala sesuatu yang diciptakan oleh Allah di muka bumi ini pada asalnya adalah halal dan mubah. Tidak ada satupun yang haram, kecuali karena ada nash yang sah dan tegas dari syari' (yang membuat hukum itu sendiri) yaitu Allah dan Rasul-Nya yang mengharamkannya. Kalau tidak ada nash yang tegas (sharih) yang menunjukkan haram, maka hal tersebut tetap sebagaimana asalnya yaitu mubah.

Yusuf Qardhawi menjelaskan beberapa prinsip-prinsip Islam tentang halal dan haram yang perlu kita ketahui bersama. Prinsip-prinsip itu adalah sebagai berikut (Yusuf 2007, 33) :

1. Segala sesuatu pada asalnya mubah. 
2. Menghalalkan dan mengharamkan adalah hak Allah semata

3. Mengharamkan yang halal dan menghalalkan yang haram sama dengan syirik.

4. Mengharamkan yang halal akan mengakibatkan timbulnya keburukan dan bahaya.

5. Yang halal tidak memerlukan yang haram.

6. Apa yang membawa kepada yang haram adalah haram.

7. Bersiasat terhadap hal yang haram adalah haram.

8. Niat yang baik tidak dapat menghalalkan yang haram.

9. Menjauhkan diri dari syubhat karena takut terjatuh dalam haram.

10. Sesuatu yang haram berlaku untuk semua orang.

11. Keadaan yang terpaksa membolehkan yang terlarang.

\section{Makanan dan Minuman yang Diharamkan}

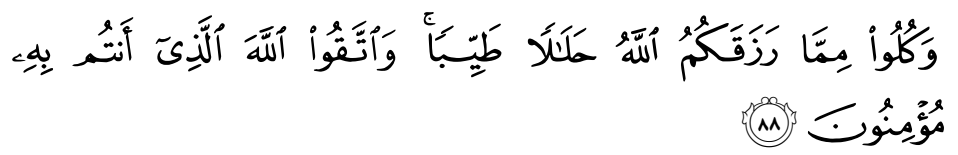

Dan makanlah makanan yang halal lagi baik dari apa yang Allah telah rezkikan kepadamu, dan bertakwalah kepada Allah yang kamu beriman kepadanya (Al-Maaidah: 88).

Ayat tersebut diatas jelas-jelas telah menyuruh kita hanya memakan makanan yang halal dan baik saja, dua kesatuan yang tidak bisa dipisahkan, yang dapat diartikan halal dari segi syariah dan baik dari segi kesehatan, gizi, estetika dan lainnya.

Sesuai dengan kaidah ushul fiqih, segala sesuatu yang Allah tidak melarangnya berarti halal. Dengan demikian semua makanan dan minuman diluar yang diharamkan adalah halal. Oleh karena itu, sebenarnya sangatlah sedikit makanan dan minuman yang diharamkan tersebut. Walaupun demikian, pada zaman dimana teknologi telah menjadi bagian yang tidak terpisahkan dari manusia, maka permasalahan makanan dan minuman halal menjadi relatif kompleks, apalagi yang menyangkut produk-produk bioteknologi. 


\section{A. Makanan yang Diharamkan}

\section{Al-Baqarah ayat 173 Allah berfirman:}

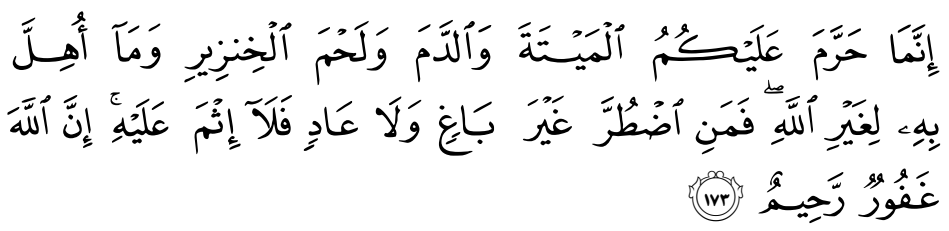

Sesungguhnya Allah hanya mengharamkan bagimu bangkai, darah, daging babi, dan binatang yang (ketika disembelih) disebut nama selain Allah. Tetapi barangsiapa dalam keadaan terpaksa (memakannya) sedang ia tidak menginginkannya dan tidak (pula) melampaui batas, maka tidak ada dosa baginya. Sesungguhnya Allah maha pengampun lagi maha penyayang (Al-Baqarah:173).

Dari ayat diatas jelaslah bahwa makanan yang diharamkan pada pokoknya ada empat:

Bangkai: yang termasuk kedalam kategori bangkai ialah hewan yang mati dengan tidak disembelih, termasuk kedalamnya hewan yang matinya tercekik, dipukul, jatuh, ditanduk dan diterkam oleh hewan buas, kecuali yang sempat kita menyembelihnya (Al-Maaidah:3). Bangkai yang boleh dimakan berdasarkan hadis yaitu bangkai ikan dan belalang (Hamka 1982).

Darah, sering pula diistilahkan dengan darah yang mengalir (Al- An'aam:145), yang dimaksud adalah segala macam darah termasuk yang keluar pada waktu penyembelihan (mengalir), sedangkan darah yang tersisa setelah penyembelihan yang ada pada daging setelah dibersihkan dibolehkan (Sayyid Sabiq 1973). Dua macam darah yang dibolehkan yaitu jantung dan limpa, kebolehannya didasarkan pada hadis (Hamka 1982).

Daging babi. Kebanyakan ulama sepakat menyatakan bahwa semua bagian babi yang dapat dimakan haram, sehingga baik dagingnya, lemaknya, tulangnya, termasuk produk-produk yang mengandung bahan tersebut, termasuk semua bahan yang dibuat dengan menggunakan bahan-bahan tersebut sebagai salah satu bahan bakunya. Hal ini misalnya tersirat dalam Keputusan Fatwa MUI bulan September 1994 tentang keharaman memanfaatkan babi dan seluruh unsur-unsurnya (Majelis Ulama Indonesia 2015). 
Binatang yang ketika disembelih disebut nama selain Allah. Menurut Hamka (1982), ini berarti juga binatang yang disembelih untuk yang selain Allah (penulis mengartikan diantaranya semua makanan dan minuman yang ditujukan untuk sesajian). Tentu saja semua bagian bahan yang dapat dimakan dan produk turunan dari bahan ini juga haram untuk dijadikan bahan pangan seperti berlaku pada bangkai dan babi.

Masalah pembacaan basmalah pada waktu pemotongan hewan adalah masalah khilafiyah (Hamka 1982), ada yang mengharuskan membacanya, ada yang hanya menyunahkan saja. Yang mengharuskan membacanya berpegang pada surat Al-An'aam ayat 121:dan janganlah kamu memakan binatang yang tidak disebut nama Allah (ketika menyembelihnya), sesungguhnya hal itu suatu kefasikan.... Bagi mereka yang menyunahkan membacanya berpegang pada hadishadis, diantaranya hadis yang dirawikan oleh Bukhari, An-Nasa-i dan Ibnu Majah dari hadis Aisyah bahwasuatukaum datang kepada kami membawakan kami daging, tetapi kami tidak tahu apakah disebut nama Allah atasnya atau tidak. Maka menjawab Rasulullah saw: "Kamu sendiri membaca bismillah atasnya, lalu makanlah!" Berkata yang merawikan: "Mereka itu masih dekat kepada zaman kufur." (Artinya baru masuk Islam) (Hamka 1982).

Ada satu masalah lagi yang masih menjadi khilafiyah yaitu sembelihan, ahli kitab ada yang membolehkan (Hamka 1982; Yusuf 2007) yang didasarkan diantaranya firman Allah dalam surat Al-Maaidah ayat 5: ... dan makanan orang-orang yang diberi AlKitab itu halal bagimu, dan makanan kamu halal bagi mereka.... Kebolehan memakan hewan ternak (selain babi) hasil sembelihan ahli kitab (Yahudi dan Nasrani) ini sepanjang cara penyembelihannya sesuai dengan cara penyembelihan secara islami (menggunakan pisau yang tajam, memotong urat lehernya dan hewan mengeluarkan darahnya pada waktu disembelih yang berarti hewan belum mati pada waktu disembelih walaupun dipingsankan dulu sebelumnya) (Hamka 1982). Yang mengharamkan sembelihan ahli kitab didasarkan pada ayat 121 surat Al-An'aam seperti dituliskan diatas, dimana mereka menyembelih tidak atas nama Allah. 
Disamping keempat kelompok makanan yang diharamkan tersebut diatas, terdapat pula kelompok makanan yang diharamkan karena sifatnya yang buruk seperti dijelaskan dalam surat Al-A 'raaf: 157

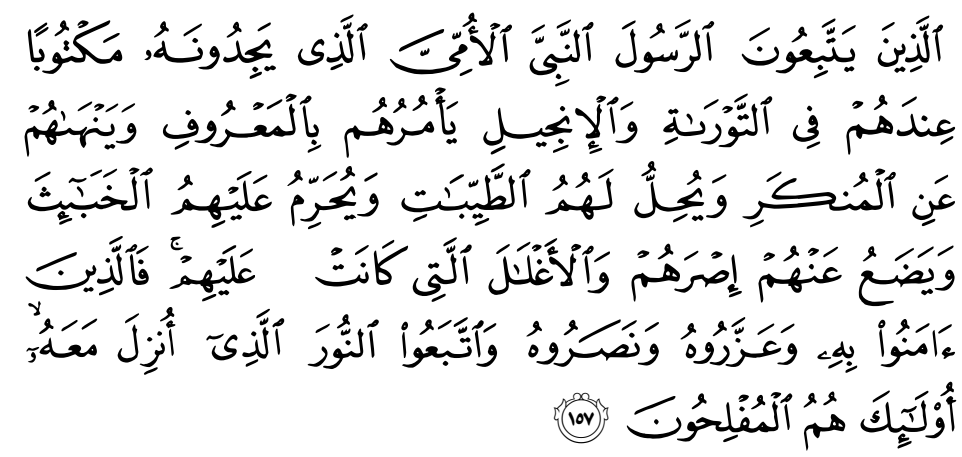

(Yaitu) orang-orang yang mengikut Rasul, Nabi yang ummi yang (namanya) mereka dapati tertulis di dalam Taurat dan Injil yang ada di sisi mereka, yang menyuruh mereka mengerjakan yang ma'ruf dan melarang mereka dari mengerjakan yang mungkar dan menghalalkan bagi mereka segala yang baik dan mengharamkan bagi mereka segala yang buruk dan membuang dari mereka beban-beban dan belenggubelenggu yang ada pada mereka. Maka orang-orang yang beriman kepadanya. memuliakannya, menolongnya dan mengikuti cahaya yang terang yang diturunkan kepadanya (Al Quran), mereka itulah orangorang yang beruntung.

dan menghalalkan bagi mereka segala hal yang baik dan mengharamkan bagi mereka segala hal yang buruk... ... Apa-apa saja yang buruk tersebut agaknya dicontohkan oleh Rasulullah dalam beberapa hadis, diantaranya hadis Ibnu Abbas yang dirawikan oleh Imam Ahmad dan Muslim dan Ash Habussunan: Telah melarang Rasulullah saw memakan tiap-tiap binatang buas yang bersaing (bertaring, penulis), dan tiap-tiap yang mempunyai kuku pencengkraman dari burung. Sebuah hadis lagi sebagai contoh, dari Abu Tsa'labah: Tiap-tiap yang bersaing dari binatang buas, maka memakannya adalah haram (perawi hadis sama dengan hadis sebelumnya).

Hewan-hewan lain yang haram dimakan berdasarkan keterangan pada hadis-hadis ialah himar kampung, bighal, burung gagak, burung elang, kalajengking, tikus, anjing, anjing gila, semut, lebah, burung hudhud, burung shard (Sayyid Sabiq 1973). Selain itu, ada lagi binatang yang tidak boleh dimakan yaitu yang disebut jallalah. Jallalah adalah 
binatang yang memakan kotoran, baik ia unta, sapi, kambing, ayam, angsa, dll sehingga baunya berubah. Jika binatang itu dijauhkan dari kotoran (tinja) dalam waktu lama dan diberi makanan yang suci, maka dagingnya menjadi baik sehingga julukan jallalah hilang, kemudian dagingnya halal (Sayyid Sabiq 1973). Ada pula Imam yang tidak mengkategorikan makanan-makanan haram yang dijelaskan dalam hadis sebagai makanan haram, tetapi hanya makruh saja. Pendapat ini dipegang oleh penganut mazhab Maliki (Hamka 1982; Sayyid Sabiq 1973). Akan tetapi, dengan menggunakan common sense saja agaknya sudah dapat dirasakan penolakan untuk memakan binatang-binatang seperti binatang buas: singa, anjing, ular, burung elang, dsb. Oleh karena itu, barangkali pendapat Mazhab Syafi ` l lah yang lebih kuat yang mengharamkan makanan yang telah disebutkan diatas.

Ada pula pendapat yang mengatakan hewan yang hidup di dua air haram, yang menurut mereka didasarkan pada hadis. Sayangnya, sampai saat ini penulis hanya dapat menemukan pernyataan keharaman makanan tersebut di buku-buku fiqih tanpa dapat berhasil menemukan sumber hadisnya yang jelas selain dari satu hadis yang terdapat dalam kitab Bulughul Maram: Dari 'Abdurrahman bin 'Utsman Al-Qurasyisyi bahwasanya seorang tabib bertanya kepada Rasulullah saw tentang kodok yang ia campurkan didalam satu obat, maka Rasulullah larang membunuhnya (Diriwayatkan oleh Ahmad dan disahkan oleh Hakim dan diriwayatkan juga oleh Abu Dawud dan Nasa i i). Dari hadis tersebut, dapat diinterpretasikan bahwa larangan membunuh kodok sama dengan larangan memakannya. Akan tetapi larangan terhadap binatang lainnya yang hidup di dua air seperti kodok tentulah tidak secara tegas dinyatakan dalam hadis tersebut, mungkin itu hanya hasil qias saja. Jadi seharusnya yang diharamkan hanya kodok saja, sedangkan hewan yang hidup di dua alam lainnya tidak diharamkan, kecuali ada hadis yang menyatakan dengan jelas keharaman hewan-hewan tersebut.

\section{B. Minuman yang Diharamkan}

Dari semua minuman yang tersedia, hanya satu kelompok saja yang diharamkan yaitu khamar. Yang dimaksud dengan khamar yaitu minuman yang memabukkan sesuai dengan penjelasan Rasulullah saw 
berdasarkan hadis yang diriwayatkan oleh Ahmad dan Abu Daud dari Abdullah bin Umar: setiap yang memabukkan adalah khamar (termasuk khamar) dan setiap khamar adalah diharamkan (semua hadis-hadis yang digunakan dalam pembahasan minuman yang diharamkan diperoleh dari Sabiq (1973). Dari penjelasan Rasulullah tsb jelas bahwa batasan khamar didasarkan atas sifatnya, bukan jenis bahannya, bahannya sendiri dapat apa saja. Dalam hal ini ada perbedaan pendapat mengenai bahan yang diharamkan, ada yang mengharamkan khamar yang berasal dari anggur saja. Akan tetapi penulis menyetujui pendapat yang mengharamkan semua bahan yang bersifat memabukkan, tidak perlu dilihat lagi asal dan jenis bahannya, hal ini didasarkan atas kajian hadis-hadis yang berkenaan dengan itu, juga pendapat para ulama terdahulu.

Mengenai sifat memabukkan sendiri dijelaskan lebih rinci lagi oleh Umar bin Khattab seperti diriwayatkan oleh Bukhari dan Muslim sebagai berikut: Kemudian daripada itu, wahai manusia! sesungguhnya telah diturunkan hukum yang mengharamkan khamar. Ia terbuat dari salah satu lima unsur: anggur, korma, madu, jagung dan gandum. Khamar itu adalah sesuatu yang mengacaukan akal. Jadi sifat mengacaukan akal itulah yang dijadikan patokan. Sifat mengacaukan akal itu diantaranya dicontohkan dalam Al-Quran yaitu membuat orang menjadi tidak mengerti lagi apa yang diucapkan seperti dapat dilihat pada surat An-Nisa: 43:

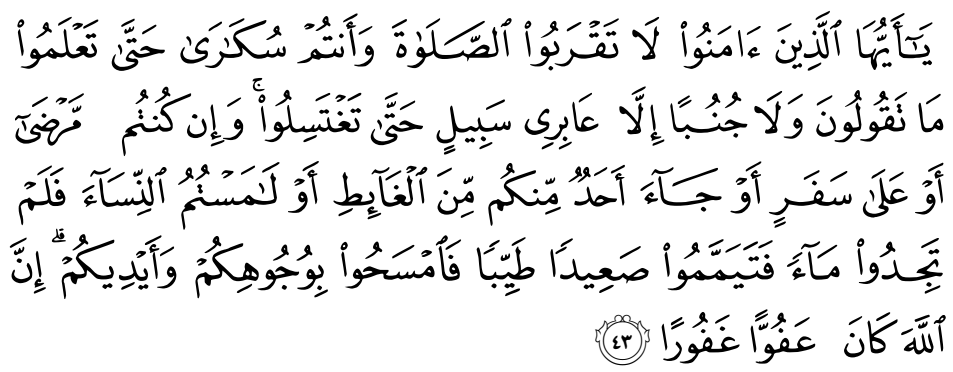

.... Hai orang-orang yang beriman! Janganlah kamu shalat sedang kamu dalam keadaan mabuk, sehingga kamu mengerti apa yang kamu ucapkan. Dengan demikian berdasarkan ilmu pengetahuan dapat diartikan sifat memabukkan tersebut yaitu suatu sifat dari suatu bahan yang menyerang syaraf yang mengakibatkan ingatan kita terganggu. Keharaman khamar ditegaskan dalam Al-Quran surat Al-Maaidah ayat 90-91: Hai orangorang yang beriman! Sesungguhnya meminum khamar, berjudi, berkorban 
untuk berhala dan mengundi nasib dengan anak panah adalah perbuatanperbuatan keji yang termasuk perbuatan syaitan. Maka jauhilah perbuatanperbuatan itu agar kamu mendapat keberuntungan. Sesungguhnya syaitan itu bermaksud hendak menumbulkan permusuhan dan kebencian diantara kamu lantaran meminum khamar dan berjudi itu dan menghalangi kamu dari mengingat Allah dan sembahyang. Maka berhentilah kamu mengerjakan perbuatan itu.

Dengan berpegang pada definisi yang sangat jelas tersebut diatas maka kelompok minuman yang disebut dengan minuman keras atau minuman beralkohol (alcoholic beverages) termasuk khamar. Sayangnya, banyak orang mengasosiasikan minuman keras ini dengan alkohol saja sehingga yang diharamkan berkembang menjadi alkohol (etanol), padahal tidak ada yang sanggup meminum etanol dalam bentuk murni karena akan menyebabkan kematian.

Batasan khamar ini nampaknya tidak terbatas pada minuman saja mengingat ada hadis yang mengatakan setiap yang memabukkan adalah khamar dan setiap khamar adalah haram (Hadis Muslim); Semua yang mengacaukan akal dan semua yang memabukkan adalah haram (Hadis Abu Daud). Dengan demikian segala hal yang mengacaukan akal dan memabukkan seperti berbagai jenis bahan narkotika termasuk ecstasy adalah haram.

Disamping makanan dan minuman yang diharamkan seperti telah dijelaskan diatas, ada beberapa kaidah fiqih yang sering digunakan dalam menentukan halal haramnya bahan pangan. Kaidah tersebut diantaranya adalah:

1. Semua yang bersifat najis haram untuk dimakan.

2. Manakala bercampur antara yang halal dengan yang haram, maka dimenangkan yang haram.

3. Apabila banyaknya bersifat memabukkan maka sedikitnya juga haram.

\section{Hukum Najis}

Pada saat ini begitu banyak bahan-bahan yang dapat digunakan untuk kosmetika. Sayangnya, banyak dari bahan-bahan tersebut berasal dari hewan, bahkan dari manusia. Hal ini jelas akan berdampak 
pada hukum kenajisan dari kosmetika tersebut. Tentu saja kosmetika haruslah hanya terbuat dari bahan-bahan yang tidak najis agar kosmetika tersebut halal dipakai, apalagi kosmetika yang dipakai pada bagian tubuh yang berhubungan dengan konsumsi makanan seperti lipstik, bukan hanya tidak boleh mengandung bahan yang najis tapi juga tidak boleh mengandung bahan yang haram karena dapat terkonsumsi secara tidak sengaja. Berdasarkan hal hal yang dikemukakan tersebut maka pentinglah kiranya untuk mengkaji kembali bahan bahan apa saja yang termasuk kedalam kategori najis ini.

Berdasarkan buku Fikih Sunnahnya Sayid Sabiq tersebut maka yang termasuk kedalam najis adalah: Bangkai, Darah, Daging babi, Muntah (kalau muntah sedikit dimaafkan), Kencing manusia, Kotoran manusia, Wadi, Madzi, Mani, Kencing dan tahi binatang yang tidak dimakan dagingnya, Binatang jalallah, Khamar, Anjing (Yusuf 2007).

Perlu diingat bahwa dalam penetapan suatu hukum, bukan hanya masalah materi saja yang dipertimbangkan, akan tetapi masalahmasalah lain seperti masalah pemanfaatan barang haram (intifa'). Dalam kasus babi misalnya, pemanfaatan babi dan unsur-unsur babi tidak diperkenankan. Itu sebabnya ada yang berpendapat jika babi haram dan najis maka turunannya pun tidak boleh dimanfaatkan, tentu bisa ada pendapat lainnya yang tidak sama mengingat ada pula Imam yang membolehkan menggunakan bulu babi sebagai benang. Walaupun demikian, sekali lagi ditegaskan bahwa masalah najis ini belum banyak dibahas lagi, khususnya dalam kaitan penggunaannya untuk kosmetika dan toilettries, secara lebih khusus lagi adalah bahan bahan turunan dari bangkai dan babi yang ditengarai banyak digunakan dalam kosmetika dan toilettries.

\section{Istinbath dan Ijtihad}

\section{A. Istinbath}

Kata thuruq berasal dari bahasa Arab bentuk jama' (plural) dari kata thariqun yang artinya jalan, metode, atau cara. Adapun kata Istinbath secara istilah sebagaimana didefinisikan oleh Muhammad bin Ali al- Fayumi (w.770 H) seorang ahli bahasa Arab dan fiqh yaitu upaya menarik hukum dari Al Qur'an dan sunah dengan jalan Ijtihad (Shidiq 
Sapiudin 2014). Al-Qur'an dan sunah sebagai sumber hukum islam dalam mengungkap pesan hukumnya menggunakan berbagai macam cara, adakalanya dengan tegas dan adakalanya tidak tegas, ada yang melalui arti bahasanya dan ada juga dengan mengedepankan maqasid ahkamnya (tujuan hukum). Dan di satu kondisi juga terdapat pertentangan antara satu dalil dan dalil lainnya yang memerlukan penyelesaiannya. Ushul fiqh menampilkan berbagai macam cara dengan berbagai aspeknya untuk menangkap pesan-pesan hukum yang ditampilkan oleh Al Qur'an maupun sunah.

Metode penetapan hukum Islam dengan Metode istinbath dapat dilakukan dengan tiga cara. Pertama, melihat aspek kebahasaan; kedua mengkaji maqasid syariah (tujuan hukum) dan ketiga, penyelesaian beberapa dalil yang secara lahiriah bertentangan (Satria Effendi M Zein 2009). Para Mujtahidin dengan mempelajari Usul Fiqh dapat mengetahui dan mempraktekkan kaidah-kaidah cara mengeluarkan hukum dari dalilnya. Ulama ushul fiqh menetapkan bahwa untuk mengeluarkan hukum harus mengetahui Kaidah Syar'iyyah dan Kaidah Lughawiyyah.

\section{Kaidah Syar'iyyah,}

adalah ketentuan umum yang ditempuh Syara' dalam menetapkan hukum dan tujuan penetapan hukum bagi subyek Hukum (Mukallaf). Adapun diantaranya adalah:

\section{a. Istidal}

Prinsip dalam istidlal dalam menetapkan hukum ialah:

1. melihat pada Al Qur'an; Al Qur'an sebagai dasar pertama dalamistidlal. Dengan kata lain. Al Qur'an ialah sumber dari segala sumber Hukum Islam.

2. Melihat pada As Sunnah; As Sunnah sebagai penjelas Al Qur'an di samping penetap hukum baru apabila dalam Al Qur'an tidak terdapat dasar hukum tersebut.

3. melakukan Ijtihad dalam menggunakan atau memahami dalil; baik dalam Al quan maupun As Sunnah, bila menghadapi dalil atau dalalah yang dhanniyah. 
4. melakukan Ijtihad dalam menghadapi dua atau beberapa dalil yang kekuatannya sama atau dhahirnya bertentangan (ta'arudul adillah).

\section{b. Tujuan penetapan Hukum}

1. Tujuan pokok penetapan hukum Islam bagi mukallaf adalah untuk kemaslahatan hidup manusia

2. Dalam mencapai kemaslahatan ini, diadakan pembagian tiga kulifikasi:

- Tingkat Dlaruriy, yang tidak boleh tidak harus ada, dan dilaksanakan, dalam rangka menciptakan lima kemaslahatan yaitu: Agama, Jiwa, Akal, Harta, Keturunan.

- Tingkat Hajjiy, diwujudkan dalam rangka menghindari kesulitan pelaksanaan dan kesempatan dalam pengamalan.

- Tingkat Tahsiniy, diwujudkan dalam rangka untuk memperkokoh dan memperindah bangunan hukum, dengan mendasarkan pada Akhlaq yang mulia.

3. Tertib dari tiga tingkatan itu, ialah bahwa tingkat dlaruriy menduduki tingkat yang paling penting, yang tidak dapat dihilangkan. Tingkat kedua ialh Hajjiy, sebagai penyempurna tingkat Dlaruriy dan tingkat ketiga adalah tingkat Tahsisniy, sebagai penyempurna tingkat Hajjiy. Karenanya tidak dapat ditempuh Tahsiniy, kalau dengan menempuhnya akan menghilangkan Hajjiy, demikian pula tidak dapat ditempuh yang hajjiy, kalau dengan mewujudkan yang hajjiy itu akan menghilangkan yang Dlaruriy.

\section{c. Prinsip Penetapan Kemaslahatan}

Dalam mewujudkan kemaslahatan itu, Syara'menetapkan prinsipprinsip kaidah Kuliyah.

1. Semua yang mengandung madlarat harus dijauhi atau dihilangkan

2. Dalam menghindari dan menghilangkan yang mudlarat ditempuh pula prinsip-prinsip: Dalam menghilangkan yang madlarat, tidak boleh dengan menempuh madlarat yang sama atau yang 
lebih berat madlaratnya. Dalam menghilangkan madlarat yang umum boleh ditempuh dengan madlarat yang khusus, atau yang lebih ringan.

3. Menghindari yang mengandung kerusakan lebih diutamakan sekedar mendatangkan maslahat, karena prinsip Hukum Islam adalah mendatangkan kemaslahatan dan sekaligus menolak kemadlaratan.

4. Pada prinsipnya, dalam mencapai kemaslahatan, segala yang mendatangkan kesulitan hidup dihilangkan.

\section{d. Kemaslahatan Umum dan Kemaslahatan Perorangan}

Kemaslahatan manusia yang dituju oleh penetapan hukum adalah kemaslahatan umum (masyarakat) dan ada kalanya untuk kemaslahatan orang seorang dan bahkan adakalanya untuk keduanya sekaligus. Kalau yang dititu kemaslahatan umum, maka itu termasuk Haqqullah. Kalau yang dituju kemaslahatan semata, dalam hal hak pribadi, maka hal ini masuk Haqqul'ibad. Yang termasuk ini ialah urusan aqad kebendaan.

\section{e. Saaudz Dzarie'ah}

Untuk mencapai kemaslahatan kadang-kadang syara, harus menetapkan sesuatu larangan terhadap hal-hal yang mestinya tidak dilarang. Artinay melarang sesuatu yang semula tidak dilarang, agar tidak terjadi kerusakan.

\section{Kaidah Lughawiyyah}

Kaidah ini berasal dari ketentuan-ketentuan ahli bahasa yang dijadikan sandaran ulama ushul dalam memahami arti lafadh menurut petunjuk lafadh dan susunannya. Timbul pertanyaan dalam masalah lafadh, adakah proses terjadinya lafadz itu berdasarkan penetapan istilah ataukah dengans endirinya ataukah sebagian ditetapkan dengan istilah dan sebagian lagi terjadi dengan sendirinya dalam masyarakat? Masalah ini telah menjadi perselisihan Ulama', masing-masing mengemukakan pendapatnay dengan mendatangkan bukti-bukti yang tak penting.

\section{B. Ijtihad}

Sedangkan ijtihad menurut bahasa, kata Ijtihad berasal dari bahasa Arab, yaitu bentuk masdar dari kata Ijtahada yajtahid yang artinya 
mengerahkan segala kesanggupan untuk mengerjakan sesuatu yang sulit. Berdasarkan pengertian bahasa ini, maka tidak tepat jika kata ijtihad digunakan untuk ungkapan "orang itu berijtihad dalam mengangkat tongkat”. Sebab mengangkat tongkat adalah perbuatan mudah dan ringan yang bisa dilakukan oleh siapa saja.

Menurut definisi sebagian ulama ushul fiqh sebagaimana dikutip oleh Abu Zahra bahwa ijtihad adalah "mencurahkan segala kesanggupan dan kemampuan semaksimal mungkin itu adakalanya dalam istinbath (penetapan) hukum syariat adakalanya dalam penerapan hukum (Zahra 1995).

Posisi Ijtihad memilik dasar yang kuat dalam ajaran hukum islam. Dalam Al Qur'an terdapat ayat-ayat yang menunjukkan perintah untuk berijtihad, baik diungkapkan secara isyarat maupun secara jelas.

\section{Surat an- Nisa/4 ayat 105}

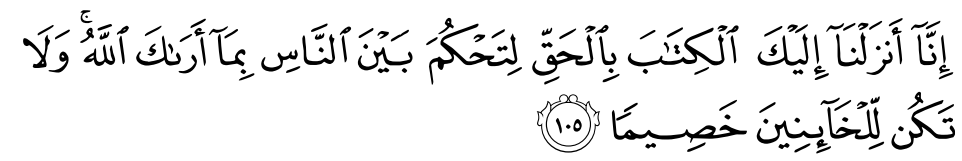

Sesungguhnya Kami telah menurunkan kitab kepadamu dengan membawa kebenaran, supaya kamu mengadili antara manusia dengan apa yang telah Allah wahyukan kepadamu, dan janganlah kamu menjadi penantang (orang yang tidak bersalah), karena (membela) orang-orang yang khianat,

ayat diatas menurut Wahbah Zuhaili mengandung legalitas ijtihad melalui metode qiyas.

\section{Surat An-nisa/4 ayat 59}

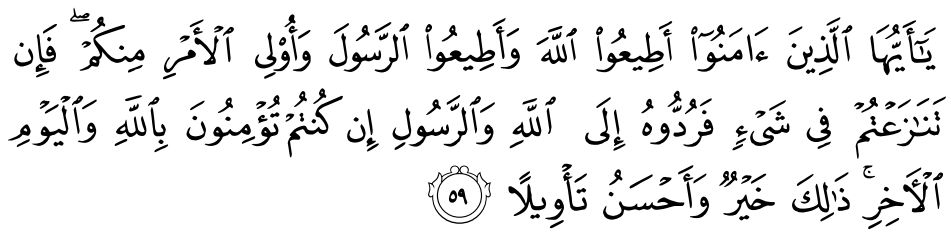

Hai orang-orang yang beriman, taatilah Allah dan taatilah Rasul (Nya), dan ulil amri di antara kamu. Kemudian jika kamu berlainan pendapat tentang sesuatu, maka kembalikanlah ia kepada Allah (Al Quran) dan Rasul (sunnahnya), jika kamu benar-benar beriman kepada Allah dan 
hari kemudian. Yang demikian itu lebih utama (bagimu) dan lebih baik akibatnya.

pada ayat diatas terdapat perintah untuk mengembalikan sesuatu yang diperselisihkan kepada Allah(al-Qur'an) dan rasul-Nya (sunah). Hal ini menunjukkan perintah berijtihad dengan tidak mengikuti hawa nafsu tetapi menjadikan al-Qur'an dan sunah sebagai sumbernya.

Hadist HR Bukhari dan HR Turmudzi juga dapat dijadikan dasar hukum ijtihad sebagai salah satu sumber hukum setelah al-Qur'an dan sunah.

Di zaman nabi orang tidak butuh ijtihad. Karena permasalahan baru yang belum ada hukumnya dapat ditanyakan langsung kepada Nabi dan Nabi langsung menjawabnya berdasarkan petunjuk wahyu yang terjamin kebenarannya. Setelah nabi wafat barulah ijtihad diperlukan oleh ulama mujtahid untuk menjawab hukum permasalahan baru yang timbul dengan tetap berpegang kepada prinsip-prinsip yang terkandung dalam al Qur'an. Permasalahan yang timbul sekarang ini sangat kompleks dan jawabannya tidak terdapat dalam al-Qur'an maupun hadist. Jika tidak ada usaha yang sungguh-sungguh dariorang yang pantas berijtihad, maka akan terjadi kekosongan hukum. Hal ini tidak sejalan dengan tujuan hukum. Oleh karena itu, ijtihad untuk sekarang ini merupakan hal yang dharury (mendesak) untuk dilakukan, karena begitu bnayak kasus permasalahan baru yang sifatnya kompleks dan rumit yang memerlukan jawaban dari hukum Islam (Shidiq Sapiudin 2014).

Untuk melakukan Ijtihad, menurut Azhar Basyir ada beberapa cara yang dapat ditempuh oleh seorang mujtahid, adalah:

a. Qiyas, dengan acar menyamakan hukum sesuatu dengan hukum lain yang sudah ada hukumnya dikarenakan adanya persamaan sebab. Contoh mencium istri ketika berpuasa hukumnya tidak membatalkan puasa karena disamakan dengan berkumur-kumur.

b. Maslaha mursalah, yaitu menetapkan hukum yang sama sekali tidak ada nashnya dengan pertimbangan untuk kepentingan hidup manusia yang bersendikan kepada asas menarik manfaat dan menghindari mudharat, contoh mencatat pernikahan. 
c. Istihsan, adalah memandang sesuatu lebih baik sesuai dengan tujuan syariat dan meninggalkan dalil khusus dan mengamalkan dalil umum. Contoh, boleh menjual harta wakaf karena dengan menjualnya akan tercapai tujuan syariat yaitu membuat sesuatu itu tidak mubazir.

d. Istishab, ialah melangsungkan berlakunya ketentuan hukum yang ada sampai ada ketentuan dalil yang mengubahnya. Contoh, segala makanan dan minuman yang tidak ada dalil keharamannya maka hukumnya mubah.

e. Urf, ialah kebiasaan yang sudah mendarah daging dilakukan oleh suatu kelompok masyarakat. Ada dua macam urf. Pertama urf sahih yaitu urf yang dapat diterima oleh masyarakat secara luas, dibenarkan oleh akal sehat, membawa kebaikan dan sejalan dengan prinsip nash. Kedua urf fasid, yaitu kebiasaan jelek yang merupakan lawan urf sahih.

\section{Metode Penetapan Fatwa MUI tentang Produk Halal}

Dasar-dasar dan prosedur penetapan fatwa yang dilakukan oleh Majelis Ulama Indonesia (MUI) dirumuskan dalam Pedoman Penetapan Fatwa Majelis Ulama Indonesia Nomor: U-596/MUI/X/1997 (MUI 1997) yang ditetapkan pada tanggal 2 Oktober 1997. Dasar-dasar penetapan fatwa dituangkan pada bagian kedua pasal 2 yang berbunyi:

1. Setiap Keputusan Fatwa harus mempunyai dasar atas Kitabullah dan Sunnah Rasul yang mu'tabarah, serta tidak bertentangan dengan kemaslahatan umat.

2. Jika tidak terdapat dalam Kitabullah dan Sunnah Rasul sebagaimana ditentukan pada pasal 2 ayat 1, Keputusan Fatwa hendaklah tidak bertentangan dengan ijma', qiyas yang mu'tabar, dan dalil-dalil hukum yang lain, seperti ihtisan, maslahah mursalah, dan saddu al-dzariah.

3. Sebelum pengambilan Keputusan Fatwa, hendaklah ditinjau pendapat-pendapat para Imam Madzhab terdahulu, baik yang berhubungan dengan dalil-dalil hukum maupun yang berhubungan dengan dalil-dalil yang dipergunakan oleh pihak yang berbeda pendapat. 
Pandangan tenaga ahli dalam bidang masalah yang akan diambil Keputusan Fatwanya, dipertimbangkan (BIMAS ISLAM 2003). Dasardasar penetapan fatwa atau disebut dengan metode istinbath hukum yang digunakan oleh MUI tidak berbeda jauh dengan metode istinbath hukum yang digunakan oleh para ulama salaf. Sikap akomodatif yang digunakan dalam penetapan fatwa MUI adalah perlunya memikirkan kemaslahatan umat ketika menetapkan fatwa, di samping itu juga perlunya memperhatikan pendapat para ulama madzhab fikih, baik pendapat yang mendukung maupun yang menentang, sehingga diharapkan apa yang diputuskan tersebut tidak cenderung pada kedua ekstrimitas, tetapi lebih mencari jalan tengah antara dua pendapat yang bertolak belakang tersebut. Solusi cemerlang yang diberikan oleh MUI dalam menetapkan fatwa adalah perlunya mengetahui pendapat para pakar di bidang keilmuan tertentu sebagai bahan pertimbangan dalam penetapan fatwanya.

Sebelum menetapkan suatu fatwa, MUI (dalam hal ini Komisi Fatwa atau tim khusus) harus terlebih dahulu mempelajari setiap masalah yang disampaikan kepada MUI dengan seksama sekurang-kurangnya seminggu sebelum disidangkan. Jika persoalannya telah jelas hukumnya (qath'iy) hendaklah komisi menyampaikan sebagaimana adanya, dan fatwa menjadi gugur setelah diketahui nash-nya dari Al-Quran dan Sunnah. Sedangkan dalam masalah yang terjadi khilafiyah (perbedaan pendapat) di kalangan madzhab, maka yang difatwakan adalah hasil tarjih setelah memperhatikan fikih muqaran (perbandingan) dengan menggunakan kaidah-kaidah ushul fiqih muqaran yang berhubungan dengan pentarjihan. (pasal 3)

Setelah melakukan pembahasan secara mendalam komprehensif, serta memperhatikan pendapat dan pandangan yang berkembang dalam sidang, komisi menetapkan fatwa. Setiap Keputusan Fatwa harus ditanfidz-kan setelah ditandatangani oleh Dewan Pimpinan dalam bentuk Surat Keputusan Fatwa (SKF). Di dalam SKF, harus dicantumkan dasardasar pengambilan hukum disertai uraian dan analisis secara ringkas, serta sumber pengambilannya. Demikian pula setiap SKF sedapat mungkin disertai dengan rumusan tindak lanjut dan rekomendasi dan atau jalan keluar yang diperlukan sebagai konsekuensi dari SKF tersebut. 
Majelis Ulama Indonesia, secara hierarkis ada dua, yaitu Majelis Ulama Indonesia Pusat yang berkedudukan di Jakarta dan Majelis Ulama Indonesia daerah. Majelis Ulama Indonesia Pusat berwenang mengeluarkan fatwa mengenai permasalahan keagamaan yang bersifat umum dan menyangkut permasalah umat Islam indonesia secara nasional dan atau masalah-masalah keagamaan yang terjadi di daerah, nsmun efeknya dapat meluas ke daerah-daerah lain, bahkan masalahmasalah tersebut bisa menasional.

Meskipun ada hirarki antara MUI pusat dan MUI daerah, namun fatwa yang dikeluarkan kedua lembaga tersebut adalah sederajat, artinya bahwa fatwa yang satu tidak bisa membatalkan fatwa yang lain. Masingmasing fatwa berdiri sendiri sesuai dengan lokalitas dan kondisinya namun ketika keputusan MUI Daerah dan MUI Pusat ada perbedaan dalam masalah yang sama, maka kedua pihak bertemu untuk mencari penyelesaian yang terbaik, agar putusan tersebut tidak membingungkan umat Islam (H.M. Atho Mudzhar 1998, 134).

Hasil keputusan Ijtima' Ulama Komisi Fatwa se Indonesia tentang Masail Qanuniyah salah satunya adalah RUU Jaminan Produk Halal, dimana masalah jaminan produk halal saat ini pada dasarnya telah diatur oleh berbagai peraturan antara lain: (1)UU. No 7 tahun 1996 tentang pangan; (2) UU No 8 tahun 1999 tentang perlindungan konsumen; (3) Peraturan Pemerintah No 69 tahun 1999 tentang label dan Iklan Pangan; (4) Keputusan Menteri Kesehatan RI No 82/Menkes/SK/ I/1996 tentang pencantuman tulisan "Halal" pada label Makanan yang direvisi dengan keputusan Menteri kesehatan RI No 924/Menkes/ SK/VIII/1996; (5) dan beberapa peraturan lain yang dikeluarkan oleh departemen Pertanian (Majelis Ulama Indonesia 2015).

"Makanlah makanan yang halal lagi baik", demikianlah perintah Allah kepada umat Islam seperti tertera dalam Al-Qur'an dalam surat AlMaaidah ayat 88. Dengan demikian mengkonsumsi makanan yang halal merupakan suatu kewajiban bagi umat Islam. Akan tetapi, dalam era global sekarang ini penetapan kehalalan suatu produk pangan tidaklah semudah pada waktu teknologi belum begitu berkembang (Qardhawi Yusuf 1995). Dengan demikian diperlukan adanya suatu jaminan dan kepastian akan kehalalan produk produk pangan yang dikonsumsi oleh 
umat Islam yang merupakan bagian terbesar penduduk Indonesia (lebih dari $85 \%)$.

Jaminan kehalalan suatu produk pangan dapat diwujudkan diantaranya dalam bentuk sertifikat halal yang menyertai suatu produk pangan, yang dengan sertifikat tersebut si produsen dapat mencantumkan logo halal pada kemasannya. Masalahnya, bagaimana menjamin bahwa sertifikat halal tersebut telah memenuhi kaidah syariah yang ditetapkan dalam penetapan kehalalan suatu produk pangan, dalam hal ini akan berkaitan dengan kompetensi lembaga yang mengeluarkan sertifikat, standar halal yang digunakan, personil yang terlibat dalam sertifikasi dan auditing, dan yang tak kalah pentingnya adalah mekanisme sertifikasi halal itu sendiri. Dengan demikian, diperlukan adanya suatu standar dan sistem yang dapat menjamin kebenaran hasil sertifikasi halal.

Kasus-kasus besar yang berkaitan dengan kehalalan produk pangan telah terjadi di Indonesia yang telah banyak merugikan banyak pihak dan menimbulkan keresahan masyarakat. Kasus pertama terjadi pada tahun 1988 yaitu adanya issue lemak babi pada banyak produk pangan, sedangkan kasus kedua adalahvaksin yang mengandung unsur babi. Belajar dari kasus yang terjadi tersebut maka Majelis Ulama Indonesia (MUI) berusaha berperan untuk menenteramkan umat Islam dalam masalah kehalalan produk pangan dengan cara mendirikan Lembaga Pengkajian Pangan, Obat-obatan dan Kosmetika MUI (LPPOM MUI) yang bertugas untuk melakukan pengkajian kehalalan produk pangan, obat dan kosmetika. Sebagai upaya untuk memberi kepastian mengenai kehalalan produk pangan maka pada perjalanan selanjutnya LPPOM MUI mulai melakukan kegiatan sertifikasi halal bagi produk pangan pada tahun 1994.

Kegiatan ini ternyata masih menemui kendala karena pihak pemerintah (melalui Depkes dan Depag) sebagai pihak yang merasa berwenang dalam pengawasan pengaturan produk pangan dan kaitannya dengan halal sekalipun, merasa pula berhak dalam melakukan sertifikasi halal ini. Melalui berbagai pertemuan dan pembahasan maka tercapailah titik temu dimana masalah sertifikasi halal akan ditangani oleh tiga lembaga yaitu MUI, Depkes dan Depag dimana ketiga lembaga tersebut menandatangani SKB (surat keputusan bersama) 3 lembaga tersebut 
yang dilakukan pada tahun 1996. Dengan bantuan kementerian negara urusan pangan maka lahirlah Undang-Undang Pangan pada tahun 1996 dimana masalah halal juga diperhatikan walaupun sangat disayangkan masih bersifat ambiguous (akan didiskusikan lebih lanjut). Melalui perjuangan yang panjang yang dimotori oleh YLKI lahir pula UndangUndang Perlindungan Konsumen yang mulai berlaku tahun 2000 dimana masalah label halal tercakup dalam UU ini. Sebelumnya, lahir pula Peraturan Pemerintah tentang Label dan Iklan Pangan pada tahun 1999 dimana label halal juga diatur dalam peraturan tersebut. Seperti tercantum dalam PP No. 69 tentang Label dan Iklan Pangan, Komite Akreditasi Nasional (KAN), Badan Standarisasi Nasional (BSN) merupakan lembaga yang melakukan akreditasi terhadap lembaga pemeriksa yang akan memeriksa kebenaran pernyataan halal yang akan dicantumkan pada label suatu produk pangan.

Dengan dasar inilah BSN membentuk suatu tim Pengembangan Akreditasi Lembaga Sertifikasi Halal pada tahun 2001. Tim ini beranggotakan personil yang mewakili lembaga pemerintah (Deptan, Badan POM, Deperindag, Depag), asosiasi industri pangan, konsumen (YLKI dan Yayasan Lembaga Konsumen Muslim), perguruan tinggi, LPPOM MUI dan BSN sendiri. Tim ini telah menghasilkan standarstandar yang diperlukan dalam masalah sertifikasi halal serta sistem sertifikasi halalnya itu sendiri (Majelis Ulama Indonesia 2015).

\section{Kesimpulan}

Dalam melakukan pengkajian masalah yang akan ditentukan hukumnya, Komisi Fatwa Majelis Ulama' Indonesia mendasarkan pada al-Qur'an dan Sunnah sebagai sumber pokok. Dalam penetapan hukum tertentu, Komisi Fatwa Majelis Ulama' Indonesia mempergunakan metode, antara lain sebagai berikut: Pertama, setiap Keputusan Fatwa harus mempunyai dasar atas Kitabullah dan Sunnah Rasul yang mu'tabarah, serta tidak bertentangan dengan kemaslahatan umat. Kedua, jika tidak terdapat dalam Kitabullah dan Sunnah Rasul, Keputusan Fatwa hendaklah tidak bertentangan dengan ijma', qiyas yang mu'tabar, dan dalil-dalil hukum yang lain, seperti ihtisan, maslahah mursalah, dan saddu al-dzari'ah. Ketiga, sebelum pengambilan 
Keputusan Fatwa, hendaklah ditinjau pendapat-pendapat para Imam Madzhab terdahulu, baik yang berhubungan dengan dalil-dalil hukum maupun yang berhubungan dengan dalil-dalil yang dipergunakan oleh pihak yang berbeda pendapat. Adapun sikap akomodatif yang digunakan dalam penetapan fatwa MUI adalah perlunya memikirkan kemaslahatan umat ketika menetapkan fatwa, sehingga apa yang diputuskan tersebut tidak cenderung pada kedua ekstrimitas, lebih mencari jalan tengah antara dua pendapat yang bertolak belakang. Salah satu solusi cemerlang yang diberikan oleh MUI dalam menetapkan fatwa adalah perlunya mengetahui pendapat para pakar di bidang keilmuan tertentu sebagai bahan pertimbangan dalam penetapan fatwanya. Pendeknya, jika persoalannya telah jelas hukumnya (qath'iy) hendaklah komisi menyampaikan sebagaimana adanya, dan fatwa menjadi gugur setelah diketahui nash-nya dari Al-Quran dan Sunnah. Sedangkan dalam masalah yang terjadikhilafyah (perbedaan pendapat) di kalangan madzhab, maka yang difatwakan adalah hasil tarjih setelah memperhatikan fikih muqaran (perbandingan) dengan menggunakan kaidah-kaidah ushul fiqih muqaran yang berhubungan dengan pentarjihan. 


\section{DAFTAR PUSTAKA}

Abd. Al-Wahhab Khallaf. 1972. Ilmu Ushul Fiqih. Jakarta: , Jakarta: AlMajlis al-A'la al Indonesia li al-dakwah al Islamiyah.

Abdul Aziz Dahlan. 1997. Ensiklopedi Hukum Islam. Jakarta: PT. Ichtiar Baru Van Hoeve.

Aisjah Girindra. 1998. LP POM MUI Sejarah Sertifikasi Halal. Jakarta: LPPOM.

Alkaf Idrus. 1998. Ijtihad Menjawab Tantangan Jaman. Solo: Ramadhani.

BIMAS ISLAM. 2003. Himpunan Fatwa Majelis Ulama Indonesia. Jakarta: Direktorat Jenderal Bimbingan Masyarakat Islam dan Penyelenggara Haji Depag RI.

H.M. Atho Mudzhar. 1998. Membaca Gelombang Ijtihad; Antara Tradisi Dan Liberasi. Yogyakarta: Titian Ilahi Press.

Hamka. 1982. Studi Islam. Jakarta: Pustaka Panjimas.

Jaih Mubarok. 2002. Metodologi Ijtihad Hukum Islam. Yogyakarta: UII Press.

Koto Alaiddin. 2004. Ilmu Fiqih Dan Ushul Fiqih. Jakarta: Rajawali Pers.

Majelis Ulama Indonesia. 2015. Fatwa MUI. Jakarta: Erlangga.

MUI. 1997. Pedoman Penetapan Fatwa Majelis Ulama Indonesia. Indonesia.

Qardhawi Yusuf. 1995. Fatwa Fatwa Kontemporer. 2nd ed. Jakarta: Gema Insani Press.

Sarwat Ahmad. 2003. Halal Atau Haram. Jakarta: Gramedia.

Satria Effendi M Zein. 2009. Ushul Fiqh. Jakarta: Fajar Interpratama Offset.

Sayyid Sabiq. 1973. Fiqih Sunnah. Bandung: PT. Alama'arif.

Shidiq Sapiudin. 2014. Ushul Fiqh. 2nd ed. Jakarta: Kencana Prenada Media Group.

Syarifuddin Halim. 2005. Meretas Kebekuan Ijtihad. Jakarta: Ciputat Press. 
Thabieb al-Asyhar. 2003. Bahaya Makanan Haram Bagi Kesehatan Jasmani Dan Kesucian Rohani. Jakarta: Al-Mawardi Prima.

Yusuf, Qardhawi. 2007. Halal Haram Dalam Islam. Jakarta: Era Intermedia.

Zahra, Muhammad Abu. 1995. Ushul Fiqih. Jakarta: PT. Pustaka Firdaus.

This page intentionally left blank 